\title{
Persepsi Remaja Mengenai Nasehat Reproduksi Pada Saat Mengalami Menarche di Garut
}

\author{
Esa Risi Suazini
}

\begin{abstract}
Abstrak
Remaja rentan terjerumus pada pergaulan bebas. Dampak pergaulan bebas diantaranya tertular Penyakit Menular Seksual (PMS). Dampak lebih besar bisa dialami oleh remaja yang telah mengalami menarche yaitu selain tertular PMS juga dapat terjadi hamil yang tidak diinginkan (KTD), Pengguguran kandungan dan kehamilan muda. Remaja perlu pembimbing dalam menghadapi kehidupan, berdasarkan data dari Kemenkes tahun 2015, sebesar $14 \%$ atau sekitar 6 juta remaja melakukan seks bebas. Masalah kesehatan reproduksi remaja bisa berlanjut pada permasalahan kesehatan reproduksi masa dewasa. Tujuan dari penelitian ini ialah mengetahui persepsi remaja putri mengenai nasihat reproduksi ketika ia mengalami menarche di Garut. Penelitian ini berguna sebagai referensi para orang tua untuk lebih memperhatikan remaja dan sebagai masukan kepada pemerintah dalam menyusun strategi baru dalam meningkatkan pengetahuan, pembentukan sikap dan perilaku remaja dalam kesehatan reproduksi. Metode penelitian yang digunakan mix method dengan cara survey kemudian wawancara untuk mendapatkan generalisasi fenomena dari persepsi responden (grounded theory). Hasil dari penelitian diperoleh jawaban bahwa mayoritas responden tidak mendapatkan nasehat reproduksi yang optimal, ibu sebagai orang utama yang memberikan nasehat reproduksi dan nasehat yang didapatkan remaja pada saat mengalami menarche ialah pergaulan secara umum, perhatian terhadap ibadah, kebersihan, jenis makanan dan minuman serta terdapat nasehat berupa mitos atau budaya yang berkembang di masyarakat.
\end{abstract}

Kata kunci : Persepri Remaja, nasehat reproduksi, menarche

\begin{abstract}
Teenagers are susceptible to falling into promiscuity. The impact of promiscuity is contracting Sexually Transmitted Diseases (STDs). Greater impact can be experienced by adolescents who have experienced menarche, other than contracting STDs can also unwanted pregnancy, abortion and young pregnancy. Adolescents need guidance in dealing with life, based on data from the Ministry of Health in 2015, amounting to 14\% or about 6 million adolescents to have free sex. Adolescent reproductive health problems can continue to reproductive health problems in adulthood. The purpose of this study was to determine the perceptions of young women regarding reproductive advice when she experienced menarche in Garut. This research is useful as a reference for parents to pay more attention to adolescents and as input to the government in developing new strategies in increasing knowledge, forming adolescent attitudes and behavior in reproductive health. The research method used is the mix method by means of a later interview survey to get a generalization of the phenomenon from the perception of the respondent (grounded theory). The results of the study obtained answers that the majority of respondents did not get optimal reproductive advice, mothers as the main people who provide reproductive advice and advice that adolescents get when experiencing menarche are general interaction, attention to worship, cleanliness, types of food and drinks and advice in the form of myths or cultures that develop in the community.
\end{abstract}

Keywords : Persepri Youth, reproductive advice, menarche 
PENDAHULUAN

Batasan usia remaja menurut Word Healht Organization (WHO) remaja ialah penduduk usia 10-19 tahun, menurut Kementerian Kesehatan Republik Indonesia melalui Permenkes RI Nomor 25 tahun 2014, remaja ialah penduduk usia 10-18 tahun dan menurut Badan Koordinasi Keluarga Berencana Nasional (BKKBN) remaja ialah penduduk usia 1024 tahun dan belum menikah). Perbedaan ini tidak menjadi fokus dalam bahasan ini, melainkan sebatas mengetahui rentang usianya. Jumlah remaja di dunia cukup banyak. Proporsi jumlah penduduk remaja hampir sama di dunia menurut WHO tahun 2014, dan di Indonesia, yaitu sekitar 18\% dari jumlah penduduk. Jumlah remaja dunia sekitar 1,2 milyar sedangkan jumlah remaja Indonesia sekitar 43,5 juta jiwa (Pusat Data dan Informasi Kementrian Kesehatan RI, 2015), (Pedoman Pengelolaan Pusat Informasi dan Konseling Remaja dan Mahasiswa, 2012).

Bentuk fisik remaja sudah hampir menyerupai fisik dewasa. Tubuh remaja putri mulai berbentuk seperti buah pir, sedangkan tubuh remaja putra mulai berbentuk seperti buah apel. Ukuran pundak remaja putri lebih kecil dibandingkan ukuran panggul, sedangkan ukuran pundak remaja laki-laki lebih besar dibanding ukuran panggulnya. Suara perempuan mengecil sedangkan suara lakilaki membesar. Manusia pada masa ini mengalami pertumbuhan dan perkembangan cepat ke 2. Percepatan pertumbuhan dan perkembangan pertama terjadi pada masa bayi, atau 1 tahun pertama kehidupan.

Hormon seks mulai aktif saat remaja. Kondisi ini menyebabkan pertumbuhan dan perkembangan seluruh tubuh. Sistem reproduksi siap melakukan fungsinya. Secara alamiah remaja mulai tertarik melakukan aktivitas seksual. Hasrat seksual terstimulasi jika berdekatan atau memandang lawan jenis. Perlu kontrol baik dari dalam diri remaja ataupun lingkungan.

Masa remaja merupakan masa unik yang penuh dengan cerita. Remaja masa yang indah. Perasaan ingin memperhatikan dan diperhatikan, rasa mencintai dan dicintai lawan jenis. Remaja ingin didengar pendapatnya dan mulai tidak ingin diatur. Gejolak rasa ini mendorong remaja ingin mengetahui, membuktikan dan mencoba semua yang dianggap baru dirasakannya. Pada masa ini remaja belum mampu meramalkan konsekuensi dari setiap perbuatan yang ia lakukan dan kejadian yang ia alami.

Perbedaan pandangan antara remaja dengan orang sekitarnya, terutama orang tua atau orng yang lebih tua darinya. Remaja tidak ingin diperlakukan seperti anak-anak, karena ia merasa dirinya sudah dewasa. Perlakuan ini berbeda dengan lingkungan tempat ia tinggal, mereka masih diperlakukan anak-anak. Remaja 
ingin mendapatkan peran lebih dalam kehidupan sosialnya, walaupun pengalaman hidup yang ia jalani belum cukup. Mereka pun ingin mendapatkan tanggung jawab lebih seperti orang dewasa, selain tanggung jawab akan dirinya sendiri.

Perubahan-perubahan fisik, mental dan sosial pada remaja ke dewasa akan terjadi. Perlu sinergisitas ketika perubahanperubahan itu terjadi. Fisik berubah, maka perlu diimbangi dengan perubahan mental dalam bentuk kematangan psikologis, kognisi atau intelektual. Dari 2 perkembangan tadi perlu dukungan sosial, sebagai pembelajaran bermasyarakat.

Kematangan mental, termasuk psikologis dan intelektual serta sosial tidak secepat pertumbuhan dan perkembangan fisik. Pertumbuhan fisik remaja sangat pesat rata-rata terjadi dalam waktu 6 sampai dengan 9 tahun, sedangkan perkembangan mental (psikologis) dan intelektual manusia tidak terbatas waktu, yaitu sejak dini hingga tua. Pembentukkan dasar-dasar mental terjadi optimal pada golden age periode yaitu pada usia 0-6 tahun dan tidak berhenti sampai waktu tersebut, melainkan perlu dilanjutkan hingga waktu yang tidak terbatas.

Perbedaan waktu dan cara untuk mencapai pertumbuhan dan perkembangan optimal antara fisik dan mental ini yang biasanya menjadi permasalahan remaja salah melangkah. Kita mungkin lebih banyak memperhatikan anak dari sisi fisik, karena itu yang terlihat, sedangkan kebutuhan anak dari sisi mental (psikologis), luput dari perhatian kita karena tidak tampak. Oleh karena itu pola asuh yang dilakukan orang tua dalam mendampingi anak sampai usia remaja perlu dipersiapkan dengan baik. terencana dan sungguh-sungguh. Bimbingan oleh orang-orang terdekat dapat memperkecil peluang remaja mengalami kejadian atau peristiwa yang merugikan.

Remaja berperan sebagai generasi penerus bangsa. Masa depan bangsa berada di tangan remaja. Potensi remaja akan berkembang dan siap menjadi dewasa yang berkepribadian unggul apabila dalam kondisi sehat. Sehat ialah kondisi tubuh dalam keadaan normal dan bugar, terhindar dari rasa sakit dan cacat, jiwa bahagia, rukun dengan sesama, serta memiliki manfaat bagi lingkungan.

Masalah kesehatan reproduksi remaja menjadi masalah hulu kesehatan ibu dan anak. Angka Kematian Ibu di Indonesia tahun 2015 ialah 305 ibu dari 100.000, bisa diartikan bahwa $0,3 \%$ ibu bersalin berakhir dengan meninggal. Kemungkinan penyebab ibu meninggal karena hamil dan bersalin dalam kondisi tidak sehat. Masalah pada saat hamil bisa disebabkan oleh masalah pada saat sebelum hamil atau pada saat sebelum menikah. Fakta di lapangan prilaku seks bebas terjadi pada $14 \%$ remaja. Angka 
tersebut menghantarkan perempuan dewasa mengalami masa obstetrik tidak sehat, mereka berpotensi tertular penyekit menular seksual termasuk HIV/AIDS. Kejadian memilukan selanjutnya, masa obstetri yang berujung pada kematian (Hermiyanti, 2015).

Penyebab seks pra nikah pada remaja antara lain perilaku pacaran, sumber informasi kesehatan reproduksi yang tidak tepat (mayoritas diperoleh dari teman, teman mungkin memberikan informasi yang salah, karena mereka bukan seorang ahli), peran orang tua, guru dan petugas kesehatan belum cukup. Orang tua sebagai orang yang paling bertanggung jawab atas anak-anaknya belum mampu menjadi teman diskusi dan memberikan informasi yang lengkap tentang kesehatan reproduksi.

Pengalaman pacaran remaja sudah biasa dilakukan remaja. Pernyataan ini berdasarkan data SDKI tahun 2012, sebanyak $80 \%$ remaja pernah berpacaran, jika jumlah remaja 43,5 juta jiwa, maka sekitar 34,8 juta orang. Berdasarkan umur mulai berpacaran, remaja sudah berpacaran sebelum 12 tahun, yaitu sekitar 1 juta orang, terbanyak remaja pacaran umur 1517 tahun, yaitu lebih dari 19 juta orang. Orang berpacaran memiliki peluang lebih besar melakukan aktivitas seksual dibandingkan dengan yang tidak berpacaran. Berdasarkan data SDKI tahun 2012, seks pranikah dilakukan lebih dari 6 juta remaja umur 20-24 tahun. Data tersebut menunjukkan peningkatan sebesar $30 \%$ dari perilaku seks remaja tahun 2007. Seks pra nikah menjadi salah satu penyebab kehamilan yang tidak diinginkan (KTD), kehamilan usia muda, pengguguran kehamilan dan penularan penyakit menular seksual. Alasan terbanyak remaja melakukan seks pra nikah ialah keinginan mencoba yaitu 57\%, tanpa rencana $30 \%$ dan dipaksa oleh pasangan biasa terjadi pada remaja putri yaitu 12,6\% (Pusat Data dan Informasi Kementrian Kesehatan RI, 2015).

Orang tua sebagai teman diskusi remaja seharusnya lebih dominan dibandingkan kepada orang lain, namun pada kenyataannya orang tua menjadi teman diskusi remaja putri kurang dari $43 \%$ dan teman diskusi remaja putra kurang dari 10\%. Kedekatan ibu dengan remaja putri lebih baik (42,1\%) dibandingkan kedekatan ibu terhadap remaja putra $(8,8 \%)$. Kedekatan ayah dengan remaja sangat buruk, remaja putra lebih terbuka pada ayah hanya 7,5\% sedangkan remaja putri hanya $4 \%$. Sumber informasi kesehatan dari orang tua kepada remaja putri 40\%, sedangkan kepada remaja putra hanya $12,7 \%$. Orang tua yang memberikan informasi tersebut hanya ibu. Peran terbesar sebagai teman diskusi remaja ialah teman atau sahabat, yaitu $57 \%$, selanjutnya guru 42,2\%. Peran terbesar memberikan informasi kesehatan 
reproduksi kepada remaja putri ialah petugas kesehatan 53,7\%, sedangkan pada remaja putra teman sebesar 33\%. Peran guru dalam memberikan informasi kesehatan kepada remaja putri $31,2 \%$ dan kepada remaja putra 29,6\% (Pusat Data dan Informasi Kementrian Kesehatan RI, 2015).

Pengetahuan, sikap dan praktik akan membentuk perilaku. Teknologi, teman diskusi, sumber informasi, peran orang tua dan guru berpengaruh terhadap pengetahuan, sikap dan perilaku remaja mengenai kesehatan reproduksi (Notoatmodjo, 2012).

Usia remaja perlu pendampingan yang benar dari orang-orang di lingkungannya. Masalah yang muncul, pendampingan bagi remaja masih sangat kurang. Dampak dari masalah tersebut, sebagian remaja terjerumus pada pergaulan bebas yang berdampak pada morbiditas dan mortalitas ibu. Berdasarkan pernyataan tersebut peneliti tertarik untuk meneliti secara kualitatif persepsi remaja putri mengenai nasihat reproduksi ketika ia mengalami menarche.

Sekolah Tinggi Ilmu Kesehatan (STIKes) Karsa Husada memiliki jumlah remaja yang sangat banyak dan berasal dari berbagai daerah dan latar belakang lingkungan keluarga dan masyarakat. Remaja putri yang belum mendapatkan materi tentang kesehatan reproduksi secara rinci ialah mahasiswa tingkat 1 semester I, oleh karena itu penelitian ini dilaksanakan di STIKes Karsa Husada Garut kepada mahasiswa DIII Kebidanan Tingkat 1 Semester I Tahun Ajaran 2018/2019. Rumusan masalah dari penelitian ini ialah bagaimana persepsi remaja putri mengenai nasihat reproduksi ketika ia mengalami menarche di Garut.

Tujuan dari penelitian ini ialah mengetahui persepsi remaja putri mengenai nasihat reproduksi ketika ia mengalami menarche di Garut. Tujuan khusus penelitian ini pertama mengetahui siapa saja orang yang memberi nasihat pada saat remaja mengalami menarche, mengetahui dari mana nasihat reproduksi yang remaja dapatkan saat mengalami menarche dan mengetahui nasihat apa saja yang remaja terima saat mengalami menarche. Manfaat dan kegunaan penelitian ini supaya tersusun strategi baru dalam meningkatkan pengetahuan, pembentukan sikap dan perilaku remaja dalam kesehatan reproduksi.

\section{METODE PENELITIAN}

Metode penelitian yang digunakan merupakan mix method. Penelitian dilaksanakan dengan terlebih dulu melakukan penelitian kuantitatif dengan cara survey, kemudian dilanjutkan dengan metode kualitatif, berdasarkan macamnya penelitian kualitatif ini termasuk grounded theory. Cara mengambil data dengan melakukan wawancara (Sugiyono, (2017). 
Jumlah populasi 82 orang, cara menentukan sampel dengan purposive sampling. jumlah sampel 61 orang. Kriteria inklusi dari responden ialah, remaja putri yang berada di Program Studi DIII Kebidanan Semester I Tahun Ajaran 2018/2019 yang sudah menarche dan bersedia menjadi responden (Dahlan, 2011).

\section{HASIL DAN PEMBAHASAN}

Karakteristik yang disajikan ialah usia dan usia menarche responden. Rentang usia responden 17 sampai 21 tahun, mereka termasuk remaja lanjut. Rentang Usia menarche antara usia 11-16 tahun, semua responden menarche pada usia normal.

Gambar 1. Karakteristik Usia Responden

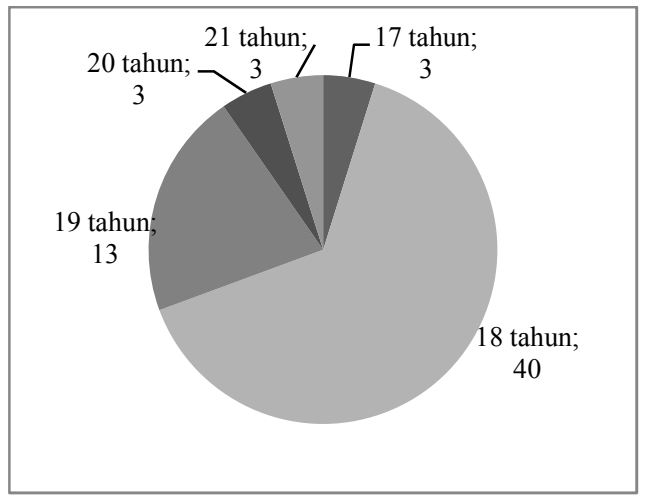

Berdasarkan survey diperoleh mayoritas responden berusia 18 tahun dan mengalami menarche usia 14 tahun. Kedua karakteristik tersebut terdapat pada gambar 1 dan 2.
Gambar 2. Karakteristik Usia Menarche

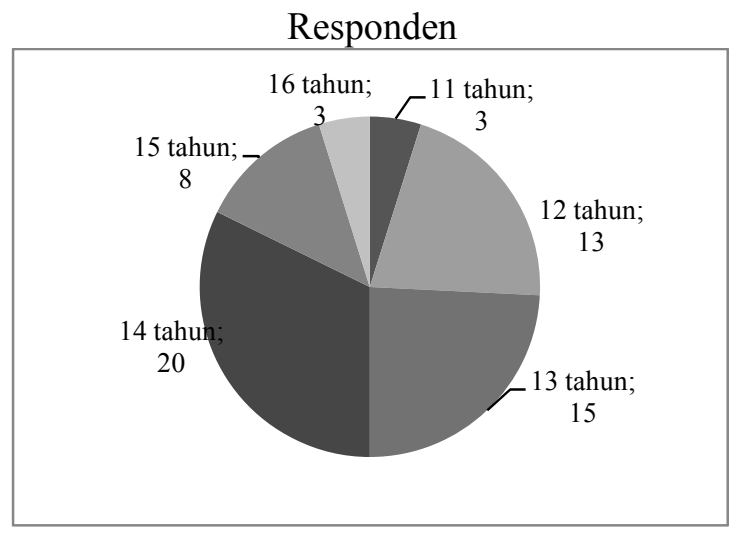

Bahasan berdasarkan tujuan penelitian yaitu berapa banyak remaja yang mendapatkan nasihat reproduksi, siapa saja yang pemberi nasihat reproduksi dan nasihat apa yang disampaikan kepada remaja saat remaja tersebut mengalami menarche.

1. Mayoritas remaja putri belum mendapatkan nasihat reproduksi, berdasarkan hasil wawancara dengan responden, ditemukan jawaban seorang remaja tidak mendapatkan nasihat apa pun pada saat ia mengalami menarche, baik dari ibu, ayah, saudara, nenek, bibi atau teman. Ditemukan seorang remaja tidak mendapatkan nasihat reproduksi namun mendapat informasi dari teman. Jawaban responden pernyataan dari temannya:

\section{"itu mah menstruasi perubahan ke dewasa."}

Dari pernyataan tersebut peneliti mendapat makna, peran orang tua sangat kurang dalam membekali anak menghadapi masa reproduksi. Jika kita berprasangka baik mungkin orang tua tidak tahu, sebenarnya penting nasihat 
reproduksi ketika remaja menghadapi awal masa reproduksi aktif.

Gambar 3. Responden yang Mendapat Nasihat Reproduksi



2. Orang-orang sekitar yang memberi nasihat reproduksi.

Gambar 4. Orang-Orang yang Memberi

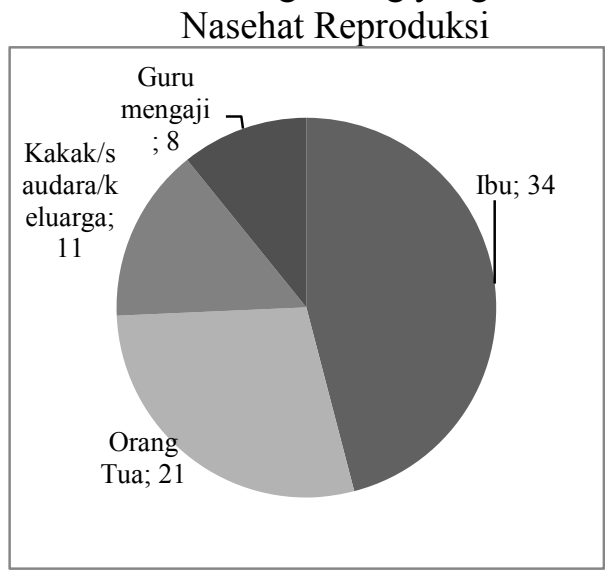

Melihat data di atas guru yang berperan dalam memberikan nasehat reproduksi ialah guru ngaji, kondisi ini sesuai dengan hasil penelitian Diana Teresa Pakasi dan Reni Kartikawati tahun 2013 yang berjudul Antara Kebutuhan dan Tabu: Pendidikan Seksual dan Kesehatan Reproduksi bagi remaja di SMA, dengan salah satu hasilnya adalah seksualitas tabu disampaikan di sekolah (Pakasi dan Kartikawati, 2013).
3. Nasihat apa yang disampaikan pada remaja saat mengalami menarche.

Nasihat yang disampaikan orangorang sekitar kepada remaja pada saat mengalami menarche dapat dilihat dari gambar 5.

Gambar 5. Jenis Nasehat yang Diterima

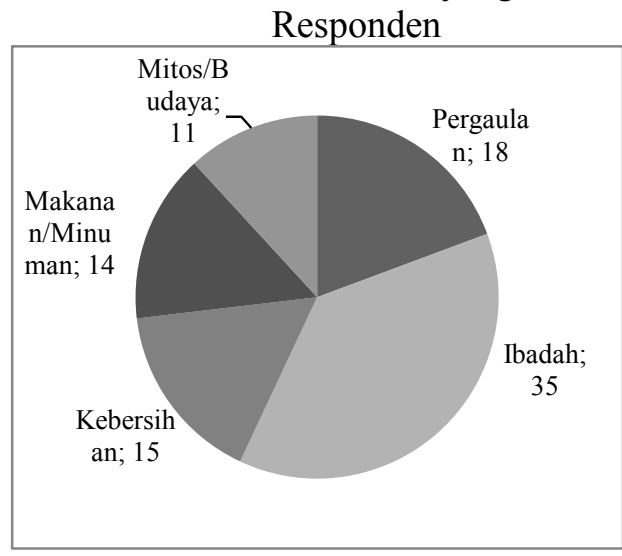

Proses penelitian yang dilakukan pertama mendapatkan jawaban responden mengenai nasihat reproduksi, kemudian peneliti melakukan transkripsi, pengkategorian dan pemaknaan. Berdasarkan hasil transkripsi ditemukan 5 kategori, yaitu pergaulan, ibadah, kebersihan, makanan/minuman dan mitos atau budaya. Remaja yang mendapatkan nasihat reproduksi pada saat menarche sebagai berikut:

a. Pergaulan

Responden mendapatkan nasihat dari orang terdekat mengenai pembatasan pergaulan terutama pergaulan dengan lakilaki, pernyataan ini sesuai dengan jawaban responden

"Jangan bergaul dengan sembarang orang."

"Jangan berdekat-dekatan dengan laki-laki bukan muhrim." 
"Harus berhati-hati jika bergaul apalagi dengan laki-laki."

"Jaga pergaulan dengan laki-laki!"

"Harus teliti dalam membersihkan darah menstruasi, jangan bilang-bilang ke lelaki."

"Jauh-jauh dari bukan mahromnya"

Berdasarkan pernyataan-pernyataan diatas, nasihat reproduksi lebih tertuju pada pergaulan lawan jenis. Pernyataan yang disampaikan orang tua sangat singkat, tidak dijelaskan alasan tidak boleh bergaul dengan lawan jenis. Karakteristik remaja saat ini perlu pemahaman mengenai alasan logis tentang perbuatan yang boleh dan tidak boleh dilakukan. Sisi lain dari kenyataan bahwa kita hidup berdampingan perempuan dengan laki-laki, baik di lingkungan pendidikan, pekerjaan atau pun bermasyarakat. Totontan dari media televisi, film, lagu, drama dan seni lainnya yang melibatkan laki-laki dan perempuan dalam satu pertunjukkan. Sangat tidak difahami apabila remaja tidak boleh bergaul dengan lawan jenis sementara larangan tersebut tidak terjadi pada kehidupan sosial di lingkungan terdekat maupun lingkungan yang lebih luas. Nasihat yang diharapkan peneliti ialah menjelaskan dampak buruk pergaulan bebas, terutama seks bebas.

Remaja tidak mungkin dilarang bergaul dengan laki-laki. Larangan yang disampaikan seharusnya menjelaskan dampak buruk secara fisik, psikologis dan sosial serta spiritual. Dampak fisik pergaulan bebas antara lain tertular penyakit menular seksual, hamil yang tidak diinginkan, pengguguran kandungan dan kehamilan muda. Dampak psikologis, mungkin hilang kepercayaan diri, bergantung pada pasangan yang belum tentu pasangan setia kepadanya, atau pasangannya belum tentu memperlakukannya dengan baik. Dampak sosial, jika remaja diketahui pernah atau melakukan seks bebas, dikucilkan keluarga, tetangga atau teman, malu berkonsultasi ketika ada masalah, baik masalah kesehatan atau pun masalah kekerasan yang dilakukan pasangan. Jika berada di lingkungan pendidikan, prilaku seks bebas merupakan pelanggaran etika berat dan akan mendapatkan hukuman dropout. Dampak spiritual yang muncul ialah pelanggaran norma agama. Tidak ada suatu agama yang melegalkan seks bebas. Walaupun kita semua tahu Tuhan Maha Pengampun, namun tidak semua makhluk mau memohon ampunan.

Pernyataan di bawah ini bisa masuk ke dalam kategori pergaulan dan ibadah, yaitu:

"Lebih dewasa lagi, sudah menanggung tanggung jawab sendiri, menanggung dosa, harus bisa lebih menutup aurat, jangan berdekatan dengan laki-laki yang bukan muhrim, jaga diri jangan sampai melakukan hal-hal yang fatal"

Pernyataan tersebut mengandung makna yang luas, terutama ungkapan “...jangan sampai melakukan hal-hal yang fatal”. Pernyataan ini bisa dimaknai tidak 
melakukan dosa besar seperti salah satunya jangan berzina. Untuk sebagian remaja mungkin faham dengan pernyataan tersebut, namun karena tidak lugas dikawatirkan remaja tahu namun tidak mampu menahan diri, sehingga masih juga berpeluang melakukan perzinahan.

Pergaulan menandakan berada di suatu lingkungan, ketika seseorang memiliki keyakinan dan perilaku baik, jika berada di lingkungan yang buruk, maka berpotensi terjadi perubahan keyakinan dan perilaku menjadi buruk. Contoh kasus seseorang yang berkeyakinan tidak berpacaran, jika lingkungan mencemooh keyakinan tersebut, mendeskriminasi, membully, bahkan menekan hubungan pertemanan, maka keyakinan tersebut bisa berubah. Oleh karena itu keluarga perlu mendidik anak dengan baik dan mengkondisikan anak termasuk remaja pada lingkungan yang baik.

b. Ibadah

Responden pada penelitian ini semua muslim. Kategori ibadah ditemukan berdasarkan jawaban responden sebagai berikut:

"Menjaga sholat."

"Rajin Sholat"

"Harus menjaga diri karena sudah baligh, punya tanggung jawab atas diri sendiri tidak meninggalkan kewajiban."

"Harus lebih baik dari sebelumnya, harus lebih giat ibadah"

"Jangan bersentuhan dengan laki-laki"

"Lebih dewasa lagi, sudah menanggung tanggung jawab sendiri, menanggung dosa, harus bisa lebih menutup aurat, jangan berdekatan dengan laki-laki yang bukan muhrim, jaga diri jangan sampai melakukan ha-hal yang fatal"

"Benar-benar menjalankan hidup, rajin ibadah, banyak berdoa, jaga diri serta kebersihan diri."

"Sholat 5 waktu tidak boleh ditinggalkan, kalau berbuat dosa sudah dicatat oleh malaikat, jadi harus berhati-hati jika bergaul apalagi dengan pria."

"Harus bisa menjadi perempuan yang lebih baik karena sudah menghadapi baligh, dimana dosa telah ditanggung sendiri, harus menjaga kebersihan lebih baik lagi."

"Katanya saya sudah baligh jadi sholat saya ga boleh bolong-bolong dan harus sudah bisa menjaga jarak dengan lawan jenis."

"Sekarang teteh sudah balig, harus lebih meningkatkan ibadahnya sholat dan mengaji tidak boleh tertinggalkan."

"Harus menutup aurat."

Pernyataan-pernyataan diatas hanya sebagian, jika dihitung berdasarkan kuantitatif, lebih dari separuh jawaban responden (56\%) nasihat yang diberikan orang terdekat ialah nasihat ibadah, seperti sholat, membaca Al-Qur'an, menutup aurat, menanamkan tanggung jawab terhadap diri sendiri dan menanamkan bahwa apa yang kita lakukan berdampak pada suatu konsekuensi serta nasihat larangan berzina.

c. Kebersihan

Nasihat yang diterima remaja tidak hanya satu beberapa inti nasihat mereka terima, seperti nasihat reproduksi bersamaan dengan nasihat kebersihan, dan nasihat ibadah. Beberapa pernyataan di bawah ini, menunjukkan bahwa kebersihan menjadi salah satu kategori nasihat untuk emaja, yaitu: 
"Harus teliti dalam membersihkan darah menstruasi, jangan dibilang-bilang ke lelaki"

"Harus menjaga kebersihan diri, dosa ditanggung sendiri"

"Selesai haid harus bisa mandi wajib, membersihkan darah harus bersih, menjaga kesehatan"

"Sering ganti pembalut, jangan menggaruk saat menstruasi"

"Cara membersihkan vagina dan pada pembalut, mengingatkan bahwa sudah baligh"

Sangat sedikit jawaban yang menyampaikan nasihat kebersihan diri yang langsung mengarah pada kesehatan, seperti informasi frekuensi ganti pembalut dalam sehari, cara membersihkan vulva yang benar dan jenis pembalut yang aman.

d. Makanan/minuman

Nasihat nutrisi yang disampaikan terbatas tidak mengkonsumsi makanan dingin, es dan pedas. Beberapa pernyataan responden:

"Jangan minum minuman dingin, jangan potong kuku saat menstruasi"

"Pada saat menstruasi tidak boleh minum air dingin, panas, tidak boleh keluar malam, tidak boleh jorok, rambut jatuh harus dikumpulkan"

"Kalau menstruasi, jangan minum air es, mencukur rambut, mandi terlalu lama, membersihkan pembalut dengan baik"

"Jangan makan yang pedas-pedas, sudah selesai haid rajin ibadah dan menutup aurat, jangan minum yang dingin, jangan keramas, jangan sering tidur"

"Tidak boleh makan pedas, minuman es, tidak boleh keramas"

Nasihat nutrisi yang seharusnya sampai kepada remaja putri ialah jenis makanan yang dapat mencegah anemia dan jenis makanan yang akan menghambat penyerapan zat besi. Perempuan pada saat menstruasi, kehilangan darah sekitar 50-80 $\mathrm{ml}$ per hari, dan dapat kehilangan zat besi sebesar 0,4-0,5 mg per hari. Kebutuhan zat besi bagi remaja berkisar 20-26 mg/hari. Makanan tau minuman yang dapat menghambat zat besi diantaranya teh, kopi, makanan sereal halus, minuman berkarbonasi, makanan dan minuman tersebut dapat menyebabkan rendahnya bioavailabilitas zat besi yang dikonsumsi (Fikawati, dkk, 2017).

Penting remaja mendapatkan kalsium yang cukup melalui informasi yang disampaikan orang-orang terdekat. Kebutuhan remaja terhadap kalsium 1.200 mg per hari (berdasarkan rekomendasi AKG 2013). Cara remaja meningkatkan asupan kalsium dalam sehari ialah pertama mengkonsumsi 3-4 porsi olahan susu rendah lemak, sayuran hijau dan kacangkacangan, kurangi konsumsi soft drink, konsumsi jus buah murni, hindari konsumsi garam (natrium) berlebih, sering berada di bawah sinar matahari dan jika tidak cukup dari makanan dapat mengkonsumsi suplemen sekitar 500 mg/hari (Pakasi dan Kartikawati, 2013).

e. Mitos atau budaya

Berdasarkan pernyataan-pernyataan responden di bawah ini mitos dan budaya yang berkaitan dengan nasihat reproduksi kepada remaja pada saat menstruasi, yaitu larangan minuman dingin, potong kuku, menggaruk terhalang baju, sering tidur, 
keramas, harus mengumpulkan rambut yang jatuh dan harus minum daun sirih. Mitos-mitos tersebut tidak berpengaruh langsung terhadap kesehatan reproduksi. Larangan keramas berhubungan dengan memungut rambut yang jatuh kemudian dimandikan pada saat mandi wajib. Mandi wajib ini harus dilakukan muslim dan muslimah ketika selesai haid, nifas, keluar sperma, senggama atau memikirkan aktivitas seksual sampai mengeluarkan sperma. Berikut kutipan pernyataan responden:

"Jangan minum minuman dingin, jangan potong kuku saat menstruasi"

"Sering ganti pembalut, jangan menggaruk saat menstruasi"

"Jangan tidur siang saat mens, jangan menggaruk terhalang baju (stretcmach)"

"Ketika haid rambut harus dikumpulkan, jangan menggunting kuku, jangan minum minuman dingin"

"Saat menstruasi minum air daun sirih"

"Ketika menstruasi jangan potong kuku dan jangan keramas"

"Pada saat menstruasi tidak boleh minum air dingin, panas, tidak boleh keluar malam, tidak boleh jorok, rambut jatuh harus dikumpulkan"

"Kalau lagi menstruasi jangan lama-lama di kamar mandi dan jangan keramas"

"Jangan makan yang pedas-pedas, sudah selesai haid rajin ibadah dan menutup aurat, jangan minum yang dingin, jangan keramas, jangan sering tidur"

"Jika terasa sakit jangan minum obat"

\section{KESIMPULAN DAN SARAN}

1. Remaja putri belum mendapatkan nasehat reproduksi optimal dari orangorang sekitar pada saat mengalami menarche.
2. Ibu pemberikan nasihat reproduksi utama bagi remaja, selanjutnya ayah, keluarga, guru ngaji dan teman.

3. Nasehat yang disampaikan kepada remaja saat mengalami menarche yaitu, pergaulan secara umum, perhatian terhadap ibadah, kebersihan, jenis makanan/minuman dan mitos/budaya. Dari nasehat yang disampaikan belum tepat mengarah pada kesehatan reproduksi.

STIKes Karsa Husada Garut

Email: esarisi91@gmail.com

DAFTAR PUSTAKA

Dahlan, M. S. (2011). Statistik untuk Kedokteran dan Kesehatan. Jakarta : Salemba Medika

Diana Teresa Pakasi dan reni kartikawati (2013). Antara Kebutuhan dan Tabu: Pendidikan Seksual dan Kesehatan Reproduksi bagi remaja di SMA. Makara Seri Kesehatan 17(2):7983.Diunduh dari: https://s3.amazonaws.com https://scholar.google.co.id

Notoatmodjo Soekidjo (2012). Promosi Kesehatan dan Perilaku Kesehatan (Edisi Revisi). Jakarta: Rineka Cipta.

Pedoman Pengelolaan Pusat Informasi dan Konseling Remaja dan Mahasiswa (PIK/ R/M).(2012). BKKBN. Diunduh dari https:www.slide share.net/rajabulgufronalenkaadespra bu/buku-pikremaja.

Pusat Data dan Informasi Kementrian Kesehatan RI (2015). Situasi Kesehatan Reproduksi Remaja. http.www.depkes.go.id.

Sandra Fikawati, Ahmad Syafiq, Arinda Veratamala (2017). Gizi Anak dan Remaja.Depok: PT Rajagrafindo Persada.

Sri Hermiyanti (2015). Kesehatan Reproduksi dan Seksual Bagi Calon Pengantin. Kemenkes RI: Jakarta 
Sugiyono (2017), Metode Penelitian

Kebijakan, Bandung: Alfabeta. 